\title{
Penggunaan Data Google Trends untuk Peramalan Tingkat Pengangguran Terbuka di Tingkat Nasional dan Regional di Provinsi Jawa Barat
}

\author{
(The Use of Google Trends Data for Forecasting The Unemployment Rate at The National and \\ Regional Levels in West Java Province) \\ Lisa Widyarsi ${ }^{1 *}$, Hardius Usman ${ }^{2}$ \\ 1,2 Politeknik Statistika STIS \\ DKI Jakarta, Indonesia \\ E-mail: 211709790@stis.ac.id
}

\begin{abstract}
ABSTRAK
Data tingkat pengangguran sangat dibutuhkan oleh pemerintah sebagai dasar dalam mengambil dan mengevaluasi kebijakan, terutama di masa krisis seperti pandemi COVID-19 ini. Namun, official statistics yang dihasilkan BPS menunjukkan lag time dalam penyajiannya dan frekuensi survei yang terbatas. Oleh karena itu, dibutuhkan data dengan frekuensi lebih banyak dan disajikan secara real time sebagai komplemen official statistics, dengan memanfaatkan big data, yang salah satunya adalah Indeks Google Trends. Penelitian ini bertujuan untuk memanfaatkan data Google Trends untuk meramalkan Tingkat Pengangguran Terbuka di Indonesia dan Jawa Barat. Penelitian ini menggunakan metode ARIMAX dengan periode penelitian Februari 2005- Februari 2020. Hasil penelitian ini menemukan bahwa indeks Google Trends dapat digunakan untuk meramal Tingkat Pengangguran Terbuka di tingkat nasional maupun regional di Jawa Barat dengan akurasi yang baik.
\end{abstract}

Kata kunci: Tingkat Pengangguran Terbuka, Big Data, Official Statistics, Google Trends, ARIMAX

\begin{abstract}
Unemployment rate data is needed by the government as a basis for making and evaluating policies, especially in times of crisis such as the COVID-19 pandemic. However, official statistics produced by BPS show lag time in presentation and limited survey frequency. Therefore, data with more frequency is needed and presented in real-time as a complement to official statistics, by utilizing big data, one of which is the Google Trends Index. This study aims to utilize Google Trends data to predict the Open Unemployment Rate in Indonesia and West Java. This study uses the ARIMAX method with a research period of February 2005-February 2020. The results of this study found that the Google Trends index can be used to predict the Open Unemployment Rate at the national and regional levels in West Java with good accuracy.
\end{abstract}

Keywords: Unemployment Rate, Big Data, Official Statistics, Google Trends, ARIMAX

\section{PENDAHULUAN}

Pada akhir tahun 2019 di Wuhan, Tiongkok muncul wabah penyakit mematikan yang disebabkan oleh virus Sars-CoV-2 yaitu CoronaVirus Disease-2019 (COVID-19), yang selanjutnya menyebabkan krisis di seluruh dunia. Salah satu dampak negatif yang ditimbulkan pandemi ini adalah dibatasinya aktivitas beberapa sektor perekonomian, sehingga perusahaan mengalami tekanan. Pada gilirannya perusahaan terpaksa melakukan Pemutusan Hubungan Kerja (PHK), yang menyebabkan meningkatnya pengangguran. Berdasarkan data yang dipublikasikan Badan Pusat Statistik (BPS) pada Agustus 2020, tingkat pengangguran terbuka (TPT) di Indonesia meningkat hingga mencapai 7,07 persen. Mengingat pengangguran merupakan permasalahan yang sensitif bagi masyarakat Indonesia, maka pemerintah harus mengambil kebijakan yang tepat dan cepat untuk menanganinya. Untuk kepentingan tersebut, salah satu elemen penting yang dibutuhkan pemerintah adalah data.

Dalam mengumpulkan data ketenagakerjaan, khususnya tingkat pengangguran, BPS menggunakan metode tradisional, yang mencakup banyak tahapan survei, dari perencanaan, pengumpulan data atau pelaksanaan lapangan, pengolahan, analisis, dan penyajian data. Akibatnya, terdapat lag atau perbedaan waktu yang relatif cukup lama antara waktu pengumpulan data dan penerbitan publikasi hasil survei. Panjangnya waktu yang dibutuhkan untuk menghasilkan official statistics ini menyebabkan pula frekuensi data yang disajikan relatif sedikit. Misalnya data Survei Ketenagakerjaan Nasional (Sakernas) hanya menghasilkan data 
TPT di bulan Februari dan Agustus dalam setahun. Padahal pemerintah membutuhkan data yang real time dan frekuensi yang terus-menerus, terutama dalam menghadapi krisis ini.

Era revolusi industri 4.0 salah satunya ditandai oleh konektivitas antara manusia, mesin, dan data yang dikenal dengan nama Internet of Things (IoT) (Kominfo, 2020). Dampak dari perkembangan teknologi tersebut adalah peningkatan kemudahan masyarakat dalam mendapatkan dan memberikan informasi, yang menyebabkanbegitu banyak data dan informasi yang tersebar. Data yang mempunyai volume besar, bervariasi, dan cepat atau dikenal dengan big data ini telah dimanfaatkan oleh akademi dan praktisi untuk berbagai kebutuhan. Salah satu sumber big data adalah orang yang mencari informasi tentang apapun melalui mesin pencari atau search engine di internet seperti Google, Yahoo, dan lain-lain.

Google merupakan mesin pencari yang paling banyak digunakan oleh masyarakat Indonesia bahkan dunia. Lee (dalam Onder, 2016) mengatakan bahwa dari semua mesin pencari yang ada, Google merupakan mesin pencari dengan persentase pengguna tertinggi dengan 67 persen pengguna dan sekitar 5,9 miliar ratarata pencarian perhari. Berdasarkan publikasi hasil survei yang dilakukan oleh We Are Social \& Hootsuite (2019), website yang paling sering diakses masyarakat Indonesia adalah Google.com dan Google.co.id dengan total kunjungan 1,7312 miliar kunjungan per bulan. Jumlah pengguna yang besar serta intensitas pencarian yang tinggi akan memberikan kontribusi terhadap peningkatan jumlah data yang dihasilkan oleh mesin pencari. Oleh karena itu, Google Trends yang mampu merefleksikan atensi masyarakat menjadi penyedia data yang sangat menunjang berbagai penelitian.

Kemudahan dan kelebihan Google Trends menjadi salah satu solusi untuk meningkatkan akurasi prediksi dalam banyak bidang penelitian. Berdasarkan penelitian sebelumnya, data Google Trends dapat digunakan sebagai informasi tambahan dalam memproyeksikan data pengangguran di Indonesia dan dapat meningkatkan performa nowcasting (Nooraeni dkk, 2020). Ketika data Google Trends dikombinasikan dengan variabel makroekonomi akan meningkatkan performa model prediksi pengangguran. Selaras dengan penelitian tersebut, indikator yang dikumpulkan Google Trends mampu menyediakan prediksi tingkat pengangguran yang lebih baik pada tingkat regional di Rumania untuk mendukung keputusan pemerintah (Mihaela, 2020). Oleh sebab itu, pemanfaatan data Google Trends dapat digunakan sebagai informasi tambahan untuk memprediksi tingkat pengangguran bersamaan dengan indikator ekonomi makro seperti pertumbuhan ekonomi dan inflasi sebagai dasar pengambilan keputusan atau evaluasi kebijakan.

Berdasarkan data Google Trends dengan kata pencarian 'Lowongan Kerja' di Indonesia, selama 1 Januari 2019 hingga 31 Desember 2019, frekuensi dengan pencarian terbanyak terdapat di Provinsi Banten dengan minat penelusuran sebesar 100 dan Provinsi Jawa Barat menduduki peringkat kelima dengan minat penelusuran sebesar 76. Selain itu, berdasarkan publikasi BPS, Tingkat Pengangguran Terbuka (TPT) di Provinsi Jawa Barat selama 5 tahun terakhir menduduki peringkat dua teratas di Pulau Jawa. Bahkan selama dua tahun terakhir, Provinsi Jawa Barat merupakan provinsi dengan TPT tertinggi kedua di Indonesia. TPT di Jawa Barat pada Februari 2019 sebesar 7,73 persen dan pada Agustus 2019 sebesar 7,99.

Berdasarkan penelitian Mihaela (2020) data Googele Trends dapat digunakan untuk peramalan pada tingkat regional. Penelitian sebelumnya belum pernah memanfaatkan data Google Trends untuk melakukan peramalan TPT pada tingkat regional di Indonesia. Kondisi yang berbeda antara Indonesia dan Rumania menjadi alasan perlunya dilakukan penelitian untuk mengetahui apakah data Google Trends di tingkat regional cukup representatif di Indonesia. Penelitian ini akan mempelajari peran data Google Trends untuk melakukan peramalan terhadap TPT di tingkat nasional dan regional di Provinsi Jawa Barat. Peramalan ini akan dilakukan dalam beberapa skenario model yaitu dengan menggunakan indikator ekonomi makro saja, data dari Google Trends saja, dan kombinasi dari indikator ekonomi makro dan dari Google Trends. Penggunaan data dari Google Trends diharapkan dapat meningkatkan akurasi dalam memprediksi tingkat pengangguran terbuka di tingkat regional di Jawa Barat serta di tingkat nasional dibandingkan hanya menggunakan variabel ekonomi makro saja.

\section{METODE}

\section{Landasan Teori}

\section{Pengangguran}

Pengangguran merupakan salah satu indikator yang dapat digunakan untuk menggambarkan kondisi ketenagakerjaan di suatu wilayah. Tingkat Pengangguran Terbuka (TPT) yang digunakan untuk mengukur keadaan pengguran adalah persentase jumlah pengangguran terhadap jumlah angkatan kerja (BPS, 2020). Pengangguran di suatu negara dipengaruhi oleh keadaan ekonomi negara tersebut. Berdasarkan Hukum Okun (Okun's law) yang dikemukakan oleh Arthur Okun, pertumbuhan ekonomi memiliki hubungan yang negatif 
dengan pengangguran (Mankiw, 2003). Pertumbuhan ekonomi yang positif akan meningkatkan kesejahteraan masyarakat dan medorong penciptaan lapangan pekerjaan sehingga berdampak pada menurunnya jumlah pengangguran. Selain itu, Teori yang dikemukakan oleh W. Phillips pada 1958 menjelaskan bahwa terdapat hubungan negatif antara inflasi dan tingkat pengangguran (Mankiw, 2003).

\section{Google Trends}

Google Trends menganalisis sebagian pencarian Google Web untuk menghitung jumlah pencarian yang telah dilakukan untuk istilah-istilah tertentu terhadap jumlah total pencarian untuk istilah yang sama di Google dari waktu ke waktu (Smith \& White, 2011). Indeks yang disajikan dalam Google Trends ini memiliki nilai dari 0 sampai 100 yang mewakili minat penelusuran untuk wilayah dan waktu tertentu. Angka 100 menggambarkan bahwa istilah penelusuran tersebut berada di puncak popularitas, nilai 50 menunjukkan istilah penelusuran berada di popularitas separuhnya, sedangkan nilai 0 menunjukkan tidak tersedia cukup informasi untuk istilah penelusuran yang digunakan.

\section{Metode Pengumpulan Data}

Penelitian ini menggunakan data time series dengan periode tiap Februari dan Agustus dari Februari 2005 hingga Februari 2020 dengan ruang lingkup penelitian di tingkat regional Provinsi Jawa Barat dan nasional. Variabel dependen yang digunakan dalam penelitian ini adalah TPT yang bersumber dari BPS. Selain itu, variabel kontrol yang digunakan adalah pertumbuhan ekonomi dan inflasi yang biasa digunakan untuk memprediksi keadaan pengangguran berdasarkan Hukum Okun dan Teori Phillips yang bersumber dari BPS. Sementara itu, variabel independen adalah indeks Google Trends yang didapatkan pada alamat https://trends.google.co.id/trends/?geo=ID dengan menggunakan kata kunci penelusuran "lowongan kerja", "loker", "bisnis", "job", dan "bursa kerja", sebagaimana yang digunakan dalam penelitian Nooraeni dkk (2020) dan Utomo (2020). Bedanya, penelitian ini juga menggunakan satu kata kunci tambahan yaitu "peluang usaha". Hal ini perlu dilakukan dalam rangka mengakomodasi pilihan pengangguran untuk mendirikan usaha ketika kesulitan mencari pekerjaan.

\section{Metode Analisis Data}

Analisis yang digunakan dalam penelitian ini adalah analisis inferensia menggunakan metode Autoregressive Integrated Moving Average Exogenous (ARIMAX). Berikut ini tahapan-tahapan dalam pembentukan model ARIMAX (Makridakis, 1998):

1. Pengecekan stasioneritas

Pengecekan stasioneritas secara subyektif dengan melihat pola korelogram ACF (autocorrelation function) dan secara statistik menggunakan Augmented Dickey-Fuller test (ADF test) pada data TPT (Gujarati, 2004). Pengujian ini harus menghasilkan nilai p-value lebih kecil dari $\alpha=5 \%$ agar dapat mengatakan bahwa tidak terdapat unit root pada data sehingga data sudah dikatakan stasioner.

2. Identifikasi ordo $\mathrm{p}, \mathrm{d}, \mathrm{q}$ untuk model ARIMA berdasarkan pola korelogram ACF dan PACF (partial autocorrelation function)

3. Estimasi model ARIMA

Persamaan ARIMA yang digunakan untuk penelitian ini adalah sebagai berikut.

$$
\begin{aligned}
\Delta^{d} T P T_{t}= & \emptyset_{0}+\emptyset_{1} \Delta^{d} T P T_{t-1}+\emptyset_{2} \Delta^{d} T P T_{t-2}+\cdots+\emptyset_{p} \Delta^{d} T P T_{t-p}+\varepsilon_{t}-\theta_{1} \varepsilon_{t-1} \\
& -\theta_{2} \varepsilon_{t-2}-\cdots--\theta_{q} \varepsilon_{t-q}
\end{aligned}
$$

Keterangan:

$\begin{array}{ll}T P T_{t} & : \text { Tingkat pengangguran terbuka pada periode berlaku } \\ T P T_{t-p} & : \text { Tingkat pengangguran terbuka pada periode lag ke-p } \\ e_{t} & : \text { error term pada periode ke-t } \\ \varepsilon_{t-q} & : \text { error term pada periode ke-(t-q) }\end{array}$

4. Uji hipotesis terhadap parameter ARIMA dengan uji t-statistik (Makridakis, 1998)

5. Uji diagnostik

Uji diagnosis digunakan untuk menguji sifat kerandoman residual (white noise) yang terdiri dari uji Ljung-Box (LB) dan uji Jarque-Bera (JB). Dalam uji LB, agar asumsi white noise terpenuhi keputusan yang diambil adalah gagal tolak $\mathrm{H}_{0}$ yaitu tidak terdapat autokorelasi antar residual pada setiap lag data atau nilai $p$ value harus lebih besar dari $\alpha$ (Makridakis, 1998). Dalam uji JB, agar asumsi white noise terpenuhi maka keputusan yang diinginkan adalah gagal tolak $\mathrm{H}_{0}$ yaitu residual berdistribusi normal dengan rata-rata nol dan varians konstan atau nilai $p$-value harus lebih besar dari $\alpha=5 \%$ (Baltagi, 2008). 
6. Estimasi parameter ARIMAX

Model ARIMA yang telah lolos uji signifikansi dan uji diagnostik dilakukan penambahan variabel $\mathrm{X}$ ke dalam modelnya. Terdapat 3 skenario model ARIMAX yang akan dibangun dalam penelitian ini, yaitu:

- Skenario pertama model ARIMAX dengan menambahkan satu kovariat Google Trends. Berikut ini persamaan model ARIMAX dari Skenario 1 yang akan diestimasi dalam bentuk notasi backshift order.

$$
(1-\emptyset(B))(1-B)^{d} T P T_{t}=(1-\theta(B)) e_{t}+\beta_{1} X_{1, t}
$$

- Skenario kedua model ARIMAX dengan menambahkan satu kovariat ekonomi makro. Berikut persamaan model ARIMAX dari Skenario 2 dalam bentuk notasi backshift order.

$$
(1-\emptyset(B))(1-B)^{d} T P T_{t}=(1-\theta(B)) e_{t}+\beta_{1} X_{1, t}
$$

- Skenario ketiga model ARIMAX dengan menambahkan dua kovariat yaitu variabel ekonomi makro dan indeks Google Trends. Berikut persamaan model dari Skenario 3 dalam bentuk notasi backshift order.

$$
(1-\emptyset(B))(1-B)^{d} T P T_{t}=(1-\theta(B)) e_{t}+\beta_{1} X_{1, t}++\beta_{2} X_{2, t}
$$

7. Uji hipotesis model ARIMAX dengan Uji t-Statistik (Makridakis, 1998)

8. Uji diagnostik model ARIMAX

Uji diagnostik model ARIMAX sama dengan uji diagnostik model ARIMA, hanya saja pada model ARIMAX skenario ketiga harus memenuhi asumsi non multikolinieritas. Asumsi non multikolinieritas terpenuhi jika nilai variance inflation factor (VIF) kurang dari 10 (Neter, Wasserman, \& Kutner, 1989).

9. Pemilihan model terbaik dengan menggunakan kriteria Akaike's Information Criterion (AIC), Schwarz's Information Criterion (SIC), Hannan-Quinn Criterion (HQ) dan Adjusted $R^{2}$.

10. Memeriksa keakuratan peramalan melalui Root Mean Square Error (RMSE), Mean Absolute Error (MAE) dan Mean Absolute Percentage Error (MAPE) yang terkecil.

\section{HASIL DAN PEMBAHASAN}

\section{Pembentukan Model ARIMA pada TPT}

Pengecekan stasioneritas dilakukan secara subyektif dengan melihat pola korelogram ACF dan secara statistik dengan uji ADF. Berdasarkan Gambar 1 dapat diketahui bahwa secara visual, data TPT Indonesia dan Jawa Barat tidak stasioner di level karena menunjukkan pola yang eksponensial. Sedangkan pada first difference data TPT Indonesia dan Jawa Barat sudah stasioner karena nilai autokorelasi di sekitar nol dan menunjukkan pola yang acak. Hasil pengujian dengan uji ADF juga menunjukkan hasil yang sama dengan pola ACF. Pada first difference, nilai $p$-value lebih kecil dari $\alpha$ sehingga data sudah stasioner.

Tabel 1. Ringkasan hasil pengujian stasioneritas variabel TPT.

\begin{tabular}{ccccc}
\hline Wilayah & Order & t-Statistik & Probabilitas & Keputusan \\
\hline Indonesia & Level atau I(0) & $-1,73207$ & 0,7088 & Tidak stasioner di level \\
& First Difference atau I(1) & $-4,91877$ & 0,0026 & Stasioner pada first difference \\
\hline Jawa Barat & Level atau I(0) & $-1,11905$ & 0,9088 & Tidak stasioner di level \\
& First Difference atau I(1) & $-7,89710$ & 0.0000 & Stasioner pada first difference \\
\hline
\end{tabular}

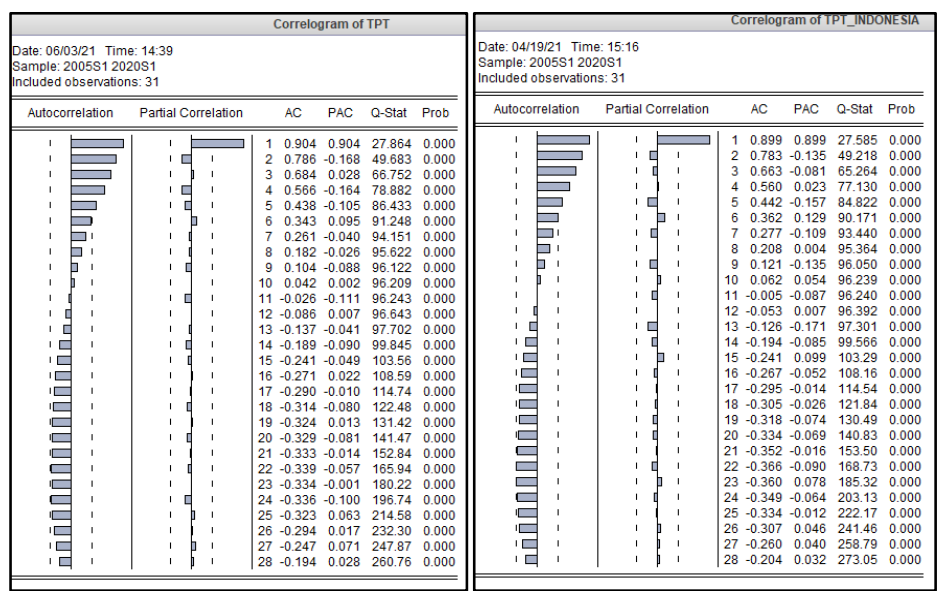

Gambar 1. Korelogram data TPT Indonesia (kiri) dan Jawa Barat (kanan) 


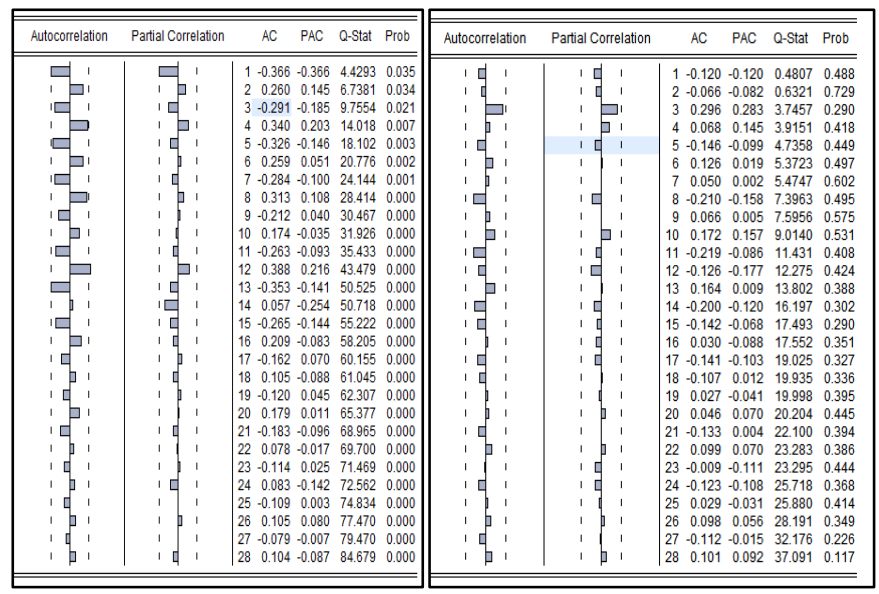

Gambar 2. Korelogram data TPT Indonesia (kiri) dan Jawa Barat (kanan) pada first difference

Selanjutnya, dilakukan identifikasi model ARIMA berdasarkan pola ACF dan PACF. Berdasarkan Gambar 2, data TPT Indonesia menunjukkan adanya spike pada lag pertama pada ACF dan PACF sehingga ordo yang mungkin AR(1) atau MA(1). Pada data ini ada indikasi efek musiman semesteran sehingga ordo $\mathrm{s}$ sebesar 2. Oleh karena itu, 10 model yang akan dicoba untuk data TPT Indonesia dapat dilihat pada Tabel 2. Berdasarkan Tabel 2 dapat disimpulkan bahwa dari 10 kombinasi model ARIMA yang telah dicoba, model ARIMA TPT Indonesia yang memiliki parameter yang signifikan pada $\alpha=5 \%$ adalah ARIMA $(0,1,0)$ dan ARIMA $(1,1,0)$.

Tabel 2. Ringkasan hasil estimasi parameter model ARIMA data TPT Indonesia.

\begin{tabular}{ccccccc}
\hline Model ARIMA & $\mathrm{C}$ & $\mathrm{AR}(1)$ & $\mathrm{MA}(1)$ & $\mathrm{SAR}(2)$ & $\mathrm{SMA}(2)$ & Keputusan \\
\hline ARIMA $(0,1,0)$ & $-0,17733^{*}$ & & & & & $\mathrm{~V}$ \\
ARIMA $(1,1,0)$ & $-0,1887^{*}$ & $-0,470018^{*}$ & & & & $\mathrm{~V}$ \\
ARIMA $(1,1,0)$ tanpa konstanta & & 0,3629 & & & & $\mathrm{X}$ \\
ARIMA $(0,1,1)$ & $-0,18827^{*}$ & & $-0,33008$ & & & $\mathrm{X}$ \\
ARIMA $(1,1,1)$ & $-0,17733^{*}$ & -1 & $0,999982^{*}$ & & & $\mathrm{X}$ \\
ARIMA $(1,1,0)(1,0,0)_{2}$ & $-0,18497^{*}$ & $-0,41382^{*}$ & & 0,129663 & & $\mathrm{X}$ \\
ARIMA $(1,1,0)(0,0,1)_{2}$ & $-0,18684$ & $-0,440545$ & & & 0,072951 & $\mathrm{X}$ \\
ARIMA $(1,1,0)(1,0,1)_{2}$ & $-0,17962$ & $-0,090667$ & & $0,997681^{*}$ & $-0,95223$ & $\mathrm{X}$ \\
ARIMA $(0,1,1)(0,0,1)_{2}$ & $-0,18617^{*}$ & & $-0,37588^{*}$ & & 0,205435 & $\mathrm{X}$ \\
ARIMA $(1,1,1)(1,0,1)_{2}$ & $-0,18202$ & $-1^{*}$ & 0,99356 & 0,794225 & $-0,99249$ & $\mathrm{X}$ \\
\hline
\end{tabular}

Keterangan: * Signifikan pada tingkat signifikansi 5\%

Sedangkan untuk Jawa Barat, pada Gambar 1 dapat dilihat bahwa pola ACF dan PACF TPT Jawa Barat tidak menunjukkan adanya spike pada lag sehingga tidak ada model tentatif yang diajukan. Karena tidak didapatkan ARIMA tentantifnya, dilakukan percobaan membentuk model ARIMA. Model ARIMA tentatif yang dibentuk dapat dilihat pada Tabel 3. Berdasarkan Tabel 3 dapat diketahui bahwa terdapat 3 model ARIMA TPT Jawa Barat yang memiliki parameter signifikan pada $\alpha=5 \%$ yaitu ARIMA $(0,1,0)$, ARIMA (1, $1,1)$ tanpa konstanta, dan ARIMA $(1,1,2)$ tanpa konstanta. Namun dua dari tiga model tersebut tidak memberikan nilai AIC yang kecil. Oleh karena itu, juga dipilih model ARIMA $(0,1,1)$, ARIMA $(1,1,0)$, ARIMA $(2,1,2)$, dan ARIMA $(3,1,0)$ berdasarkan kriteria lima model yang memiliki nilai AIC terkecil.

Tabel 3. Ringkasan hasil estimasi parameter model ARIMA data TPT Jawa Barat.

\begin{tabular}{|c|c|c|c|c|c|c|c|c|c|}
\hline Model & AIC & $\mathrm{C}$ & $\mathrm{AR}(1)$ & $\mathrm{AR}(2)$ & $\mathrm{AR}(3)$ & MA(1) & MA(2) & MA(3) & Keputusan \\
\hline ARIMA $(0,1,0)$ & 1,2618 & $-0,2340^{*}$ & & & & & & & $\mathrm{~V}$ \\
\hline $\operatorname{ARIMA}(0,1,1)$ & 1,3772 & $-0,2382 *$ & & & & $-0,1388$ & & & V \\
\hline $\operatorname{ARIMA}(0,1,2)$ & 1,4401 & $-0,2383 *$ & & & & $-0,2194$ & 0,1015 & & $\mathrm{X}$ \\
\hline $\operatorname{ARIMA}(0,1,3)$ & 1,3964 & $-0,2224 *$ & & & & $-0,1819$ & $-0,0134$ & 0,3854 & $\mathrm{X}$ \\
\hline $\operatorname{ARIMA}(1,1,0)$ & 1,3778 & $-0,2382^{*}$ & $-0,1430$ & & & & & & V \\
\hline $\operatorname{ARIMA}(1,1,1) \mathrm{C}$ & 1,4436 & $-0,2382^{*}$ & $-0,0541$ & & & $-0,0918$ & & & $\mathrm{X}$ \\
\hline ARIMA $(1,1,1)$ & 1,4873 & & $0,9776^{*}$ & & & $-0,8898 *$ & & & $\mathrm{~V}$ \\
\hline $\operatorname{ARIMA}(1,1,2)$ & 1,4720 & & $0,8621^{*}$ & & & $-1,0607 *$ & $0,4303 *$ & & V \\
\hline ARIMA $(1,1,3)$ & 1,4474 & & $0,6165^{*}$ & & & $-0,8066$ & 0,2036 & 0,5654 & $\mathrm{X}$ \\
\hline $\operatorname{ARIMA}(2,1,0)$ & 1,4388 & $-0,2392^{*}$ & $-0,1412$ & $-0,0872$ & & & & & $\mathrm{X}$ \\
\hline ARIMA $(2,1,1)$ & 1,4767 & $-0,2398 *$ & $-0,6367$ & $-0,2658$ & & 0,5258 & & & $\mathrm{X}$ \\
\hline $\operatorname{ARIMA}(2,1,2)$ & 1,3474 & $-0,2385^{*}$ & $-0,7609^{*}$ & $-0,9939^{*}$ & & 0,8362 & 1 & & $\mathrm{~V}$ \\
\hline
\end{tabular}


Tabel 3. Ringkasan hasil estimasi parameter model ARIMA data TPT Jawa Barat (lanjutan).

\begin{tabular}{cccccccccc}
\hline Model & AIC & C & AR(1) & AR(2) & AR(3) & MA(1) & MA(2) & MA(3) & Keputusan \\
\hline ARIMA(2,1,3) & 1,5225 & $-0,2140$ & 0,2656 & $-0,0511$ & & $-0,4293$ & 0,0940 & 0,3799 & X \\
ARIMA(3,1,0) & 1,3794 & $-0,2281^{*}$ & $-0,0688$ & $-0,1310$ & $0,4016^{*}$ & & & & V \\
ARIMA(3,1,1) & 1,4443 & $-0,2268$ & 0,0125 & $-0,1142$ & 0,4076 & $-0,0994$ & & & X \\
ARIMA(3,1,2) & 1,4140 & $-0,2385^{*}$ & $-0,7649^{*}$ & $-0,9968$ & $-0,0041$ & 0,8369 & 0,9987 & & X \\
ARIMA(3,1,3) & 1,4692 & $-0,2350^{*}$ & $-0,0178$ & $-0,4272$ & 0,7432 & 0,1461 & 0,4434 & $-0,6702$ & X \\
\hline
\end{tabular}

Keterangan: * Signifikan pada tingkat signifikansi 5\%

Untuk melihat apakah model ARIMA sudah memadai untuk digunakan dalam pembentukan model ARIMAX, maka dilakukan uji diagnostik dengan melihat apakah error dari model telah bersifat white noise dengan uji LB dan uji JB. Model TPT Indonesia ARIMA $(1,1,0)$ dan model TPT Jawa Barat ARIMA (0, 1 , 0) sudah memenuhi asumsi white noise karena $p$-value dari uji LB untuk setiap lag lebih besar dari $\alpha=5 \%$ dan error dari model sudah berdistribusi normal karena $p$-value dari uji LB lebih besar dari $\alpha=5 \%$ yaitu 0,5880 dan 0,4142 .

Tabel 4. Ringkasan hasil evaluasi model ARIMA.

\begin{tabular}{|c|c|c|c|c|c|c|c|}
\hline \multirow[b]{2}{*}{ Wilayah } & \multirow[b]{2}{*}{ Model ARIMA } & \multicolumn{6}{|c|}{ Kriteria Pemilihan } \\
\hline & & $\begin{array}{c}\text { White } \\
\text { Noise Error }\end{array}$ & $\begin{array}{c}\text { Error berdistribusi } \\
\text { normal }\end{array}$ & $\begin{array}{l}\text { Adjusted } \\
\mathrm{R}^{2}\end{array}$ & AIC & $\mathrm{SC}$ & HQ \\
\hline \multirow{2}{*}{ Indonesia } & ARIMA $(0,1,0)$ & $\mathrm{X}$ & V & 0 & 1,1916 & 1,2383 & 1,2065 \\
\hline & ARIMA $(1,1,0)$ & $\mathrm{V}$ & $\mathrm{V}$ & 0,1189 & 1,1352 & 1,2753 & 1,1800 \\
\hline \multirow{7}{*}{ Jawa Barat } & ARIMA $(0,1,0)$ & $\mathrm{V}$ & $\mathrm{V}$ & 0 & 1,261811 & 1,308518 & 1,276753 \\
\hline & ARIMA $(0,1,1)$ & $\mathrm{V}$ & $\mathrm{V}$ & $-0,05423$ & 1,377146 & 1,517266 & 1,421972 \\
\hline & ARIMA $(1,1,0)$ & V & V & $-0,05483$ & 1,377753 & 1,517873 & 1,422579 \\
\hline & $\begin{array}{l}\text { ARIMA }(1,1,1) \\
\text { tanpa konstanta }\end{array}$ & $\mathrm{X}$ & $\mathrm{X}$ & $-0,15424$ & 1,487343 & 1,627463 & 1,532168 \\
\hline & $\begin{array}{l}\text { ARIMA }(1,1,2) \\
\text { tanpa konstanta }\end{array}$ & $\mathrm{V}$ & V & $-0,09851$ & 1,471947 & 1,658773 & 1,531714 \\
\hline & ARIMA $(2,1,2)$ & $\mathrm{V}$ & $\mathrm{V}$ & 0,184044 & 1,347357 & 1,627596 & 1,437008 \\
\hline & ARIMA $(3,1,0)$ & V & $\mathrm{V}$ & 0,020936 & 1,379412 & 1,612944 & 1,454121 \\
\hline
\end{tabular}

Dari hasil di atas, model yang memenuhi uji diagnostik dan memiliki AIC, SC, dan HQ terkecil serta $R^{2}$ Adjusted terbesar untuk TPT Indonesia adalah ARIMA $(1,1,0)$ dan untuk Jawa Barat ARIMA $(0,1,0)$. Sehingga model TPT Indonesia ARIMA $(1,1,0)$ dan model TPT Jawa Barat ARIMA $(0,1,0)$ akan dilanjutkan ke tahap pembentukan model ARIMAX.

\section{Pembentukan Model ARIMAX pada TPT}

Model ARIMA yang telah lolos uji diagnostik digunakan untuk pembentukan model ARIMAX. Berikut ringkasan hasil estimasi untuk model ARIMAX TPT Indonesia dengan berbagai skenario pada Tabel 5.

Tabel 5. Ringkasan estimasi parameter model ARIMAX untuk TPT Indonesia.

\begin{tabular}{ccccccc}
\hline Model & $\mathrm{X}_{1}$ & $\mathrm{X}_{2}$ & $\mathrm{c}$ & $\mathrm{AR}(1)$ & $\mathrm{X}_{1}$ & $\mathrm{X}_{2}$ \\
\hline & Lowongan_kerja & & 0,0002 & $-0,6396^{*}$ & $-0,0044^{*}$ & \\
ARIMAX & Loker & & $-0,3466^{*}$ & $-0,6124^{*}$ & $0,0035^{* *}$ & \\
$(1,1,0)$ & Bisnis & & 0,0388 & $-0,6385^{*}$ & $-0,0060^{*}$ & \\
Skenario 1 & Job & & $-0,0650$ & $-0,6300^{*}$ & $-0,0038^{* *}$ & \\
& Bursa_kerja & & $-0,0912$ & $-0,6348^{*}$ & $-0,0062^{* *}$ & \\
& Peluang_usaha & & 0,0672 & $-0,6763^{*}$ & $-0,0064^{*}$ \\
& D(Peluang_usaha) & & $-0,1884^{*}$ & $-0,4616^{*}$ & 0,0014 & \\
\hline \multirow{2}{*}{ ARIMAX } & Pe & & 0,6385 & $-0,6151^{*}$ & $-0,1562^{*}$ \\
$(1,1,0)$ & Inf_mom & & $-0,1030$ & $-0,6011^{*}$ & $-0,2402^{* *}$ & \\
Skenario 2 & D(Pe) & & $-0,2000^{*}$ & $-0,5293^{*}$ & $-0,1426$ & \\
& D(Inf_mom) & & $-0,1872^{*}$ & $-0,18146$ & 0,4154 & \\
\hline & & D(Lowongan_kerja) & 0,5814 & $-0,6215^{*}$ & $-0,1495^{*}$ & $-0,0101$ \\
ARIMAX & & D(Loker) & 0,6346 & $-0,6180^{*}$ & $-0,1552^{*}$ & $-0,0008$ \\
$(1,1,0)$ & & D(Bisnis) & $0,7025^{* *}$ & $-0,5547^{*}$ & $-0,1740^{*}$ & $-0,0182^{* *}$ \\
Skenario 3 & Pe & D(Job) & 0,5328 & $-0,5856^{*}$ & $-0,1301^{* *}$ & 0,0120 \\
& & D(Bursa_kerja) & 0,6325 & $-0,6163^{*}$ & $-0,1558^{*}$ & $-0,0025$ \\
& & D(Peluang_usaha) & 0,6422 & $-0,6177^{*}$ & $-0,156906^{*}$ & $-0,0002$ \\
\hline
\end{tabular}


Tabel 5. Ringkasan estimasi parameter model ARIMAX untuk TPT Indonesia (lanjutan).

\begin{tabular}{|c|c|c|c|c|c|c|}
\hline Model & $\mathrm{X}_{1}$ & $\mathrm{X}_{2}$ & $\mathrm{c}$ & $\mathrm{AR}(1)$ & $\mathrm{X}_{1}$ & $\mathrm{X}_{2}$ \\
\hline & \multirow{6}{*}{ Inf_mom } & D(Lowongan_kerja) & $-0,1295$ & $-0,6018 *$ & $-0,2309 * *$ & $-0,0109$ \\
\hline & & D(Loker) & $-0,1030$ & $-0,6011^{*}$ & $-0,2394 * *$ & $-0,0001$ \\
\hline & & $\mathrm{D}$ (Bisnis) & $-0,1129$ & $-0,5488 *$ & $-0,3021 *$ & $-0,0193 * *$ \\
\hline & & $\mathrm{D}(\mathrm{Job})$ & $-0,0990$ & $-0,5575^{*}$ & $-0,1500$ & 0,0133 \\
\hline & & D(Bursa_kerja) & $-0,1082$ & $-0,6089 *$ & $-0,2458 * *$ & $-0,0045$ \\
\hline & & D(Peluang_usaha) & $-0,1032$ & $-0,5956^{*}$ & $-0,2389$ & 0,0010 \\
\hline & \multirow{6}{*}{$\mathrm{D}(\mathrm{Pe})$} & Lowongan_kerja & $-0,0118$ & $-0,7080^{*}$ & $-0,1464$ & $-0,0043^{*}$ \\
\hline & & Loker & $-0,3462 *$ & $-0,6553^{*}$ & $-0,1261$ & $0,0033 * *$ \\
\hline & & Bisnis & 0,0268 & $-0,7049 *$ & $-0,1470$ & $-0,0059 *$ \\
\hline & & Job & $-0,0820$ & $-0,6727 *$ & $-0,1299$ & $-0,0036 * *$ \\
\hline & & Bursa_kerja & $-0,1019$ & $-0,6989 *$ & $-0,1457$ & $-0,0062 *$ \\
\hline & & D(Peluang_usaha) & $-0,1999 *$ & $-0,5284^{*}$ & $-0,1422$ & 0,0001 \\
\hline & \multirow{6}{*}{ D(inf_mom) } & Lowongan_kerja & $-0,0063$ & $-0,4062$ & 0,3335 & $-0,0042 * *$ \\
\hline & & Loker & $-0,3702 *$ & $-0,3568$ & $0,4295 *$ & $0,0041 * *$ \\
\hline & & Bisnis & 0,0456 & $-0,4033$ & 0,3648 & $-0,0061^{* *}$ \\
\hline & & Job & $-0,0563$ & $-0,3817$ & $0,4094 * *$ & $-0,0040$ \\
\hline & & Bursa_kerja & $-0,0887$ & $-0,3812$ & $0,3855^{* *}$ & $-0,0062$ \\
\hline & & Peluag_usaha & 0,0772 & $-0,4780 * *$ & 0,3259 & $-0,0066^{*}$ \\
\hline
\end{tabular}

Keterangan: ** Signifikan pada taraf nyata $10 \%$; *taraf nyata 5\%

Model ARIMAX Skenario 1 untuk TPT Indonesia yang memenuhi kriteria signifikansi parameter pada taraf signifikansi $\alpha=5 \%$ adalah ARIMAX $(1,1,0)$ dengan variabel independen indeks google trends dengan kata pencarian "lowongan kerja", "bisnis" dan "peluang usaha". Model ARIMAX untuk TPT Indonesia Skenario 2 hanya terdapat 1 model ARIMAX yang memiliki koefisien signifikan pada taraf signifikansi $\alpha=$ $5 \%$, yaitu model ARIMAX $(1,1,0)$ dengan variabel independen yaitu pertumbuhan ekonomi. Untuk Skenario 3 , model yang dipilih untuk dilanjutkan ke tahap selanjutnya adalah model yang memuat seluruh kombinasi variabel ekonomi makro dan indeks google trend yang signifikan pada Skenario satu yaitu kata kunci pencarian "lowongan kerja", "bisnis" dan "peluang usaha". Sedangkan untuk ringkasan hasil estimasi parameter model ARIMA TPT Jawa Barat dapat dilihat pada Tabel 6.

Tabel 6. Ringkasan estimasi parameter model ARIMAX untuk TPT Jawa Barat.

\begin{tabular}{|c|c|c|c|c|c|}
\hline Model & $X_{1}$ & $\mathrm{X}_{2}$ & $\mathrm{c}$ & $X_{1}$ & $\mathrm{X}_{2}$ \\
\hline \multirow{3}{*}{$\begin{array}{c}\text { ARIMAX } \\
(0,1,0) \\
\text { skenario } 1\end{array}$} & Lowongan_kerja & & $-0,069689$ & $-0,005255$ & \\
\hline & d(lowongan_kerja) & & $-0,221508^{*}$ & 0,008147 & \\
\hline & Loker & & $-0,434121^{*}$ & $0,004941 * *$ & \\
\hline \multirow{9}{*}{$\begin{array}{c}\text { ARIMAX } \\
(0,1,0) \\
\text { Skenario } 1\end{array}$} & d(loker) & & $-0,255583^{*}$ & $0,009119 * *$ & \\
\hline & Bisnis & & $-0,02468$ & $-0,006886^{* *}$ & \\
\hline & $\mathrm{d}$ (bisnis) & & $-0,267812^{*}$ & $-0,013708^{*}$ & \\
\hline & Job & & $-0,181003$ & $-0,003292$ & \\
\hline & $\mathrm{D}($ job $)$ & & $-0,218639^{*}$ & $0,013554 * *$ & \\
\hline & Bursa_kerja & & $-0,266334 *$ & 0,005656 & \\
\hline & d(bursa_kerja) & & $-0,234275^{*}$ & $0,016513 * *$ & \\
\hline & Peluang_usaha & & $-0,188469$ & $-0,004678$ & \\
\hline & D(Peluang_usaha) & & $-0,234287^{*}$ & 0,001722 & \\
\hline \multirow{4}{*}{$\begin{array}{c}\text { ARIMAX } \\
(0,1,0) \\
\text { Skenario } 2\end{array}$} & $\mathrm{Pe}$ & & $-0,42559$ & 0,038024 & \\
\hline & Inf_mom & & $-0,134186$ & $-0,238663$ & \\
\hline & $\mathrm{D}(\mathrm{Pe})$ & & $-0,232057^{*}$ & 0,034549 & \\
\hline & D(Inf_mom) & & $-0,234666^{*}$ & 0,06178 & \\
\hline \multirow{9}{*}{$\begin{array}{c}\text { ARIMAX } \\
(0,1,0) \\
\text { Skenario } 3\end{array}$} & \multirow{9}{*}{$\mathrm{Pe}$} & Lowongan_kerja & $-0,131352$ & 0,011728 & $-0,005173$ \\
\hline & & loker & $-0,594454$ & 0,03204 & $0,004914 * *$ \\
\hline & & d(loker) & $-0,503278$ & 0,049093 & $0,00926 * *$ \\
\hline & & Bisnis & $-0,270184$ & 0,0493 & $-0,006981 * *$ \\
\hline & & D(Bisnis) & $-0,741098$ & 0,093495 & $-0,014597 *$ \\
\hline & & $\mathrm{D}(\mathrm{Job})$ & $-0,300451$ & 0,0162 & 0,01339 \\
\hline & & D(Bursa_kerja) & $-0,199589$ & $-0,006884$ & $0,016647 * *$ \\
\hline & & Peluang_usaha & $-0,316625$ & 0,024105 & $-0,00399$ \\
\hline & & D(Peluang_usaha) & $-0,440146$ & 0,040847 & 0,00199 \\
\hline
\end{tabular}


Tabel 6. Ringkasan estimasi parameter model ARIMAX untuk TPT Jawa Barat (lanjutan).

\begin{tabular}{|c|c|c|c|c|c|}
\hline Model & $\mathrm{X}_{1}$ & $\mathrm{X}_{2}$ & $\mathrm{c}$ & $\mathrm{X}_{1}$ & $\mathrm{X}_{2}$ \\
\hline \multirow{24}{*}{$\begin{array}{c}\text { ARIMAX } \\
(0,1,0) \\
\text { Skenario } 3\end{array}$} & \multirow{8}{*}{ Inf_mom } & Lowongan_kerja & $-0,032728$ & $-0,164885$ & $-0,004232$ \\
\hline & & D(Loker) & $-0,141925$ & $-0,275389 * *$ & $0,00976 * *$ \\
\hline & & loker & $-0,377102$ & $-0,084494$ & 0,004406 \\
\hline & & Bisnis & 0.006583 & -0.126437 & -0.006174 \\
\hline & & $\mathrm{D}$ (Bisnis) & $-0,161037$ & $-0,256567 * *$ & $-0,013921 *$ \\
\hline & & $\mathrm{D}(\mathrm{Job})$ & $-0,134842$ & $-0,202869$ & 0,012629 \\
\hline & & D(Bursa_kerja) & $-0,161379$ & $-0,174246$ & 0,015122 \\
\hline & & $\mathrm{D}$ (Peluang_usaha) & $-0,129946$ & $-0,249952$ & 0,002888 \\
\hline & \multirow{8}{*}{$\mathrm{D}(\mathrm{Pe})$} & Lowongan_kerja & $-0,068711$ & 0,032256 & $-0,005228$ \\
\hline & & Loker & $-0,437157 *$ & 0,04983 & $0,005085^{* *}$ \\
\hline & & $\mathrm{d}$ (loker) & $-0,253652^{*}$ & 0,034091 & $0,009114 * *$ \\
\hline & & Bisnis & $-0,023437$ & 0,032135 & $-0,006867 * *$ \\
\hline & & $\mathrm{D}$ (Bisnis) & $-0,266108 *$ & 0,02838 & $-0,013664 *$ \\
\hline & & $\mathrm{d}(\mathrm{Job})$ & $-0,218064 *$ & 0,013928 & 0,01337 \\
\hline & & d(Bursa_kerja) & $-0,238308 *$ & $-0,070607$ & $0,020178^{* *}$ \\
\hline & & Peluang_usaha & $-0,1904$ & 0,029778 & $-0,004307$ \\
\hline & \multirow{8}{*}{ D(inf_mom) } & Lowongan_kerja & $-0,069424$ & 0,066124 & $-0,005286$ \\
\hline & & Loker & $-0,434415 *$ & 0,059357 & $0,004933 * *$ \\
\hline & & $\mathrm{D}$ (loker) & $-0,255557 *$ & 0,012726 & $0,009051^{* *}$ \\
\hline & & bisnis & $-0,024259$ & 0,069450 & $-0,006924 * *$ \\
\hline & & $\mathrm{D}$ (Bisnis) & $-0,267861^{*}$ & 0,018535 & $-0,013646^{*}$ \\
\hline & & $\mathrm{d}(\mathrm{Job})$ & $-0,217444 *$ & 0,161473 & $0,016144 * *$ \\
\hline & & d(Bursa_kerja) & $-0,235106$ & 0,076786 & 0,016721 \\
\hline & & Peluang_usaha & $-0,185971$ & 0,068879 & $-0,005011$ \\
\hline
\end{tabular}

Keterangan: ** Signifikan pada taraf nyata $10 \%$; *taraf nyata 5\%

Model ARIMAX untuk TPT Jawa Barat Skenario 1, model ARIMAX yang memiliki koefisien parameter yang signifikan pada taraf signifikansi $\alpha=5 \%$ yaitu model yang memuat covariate $\mathrm{d}$ (bisnis). Apabila hanya satu variabel, tidak dapat dilakukan perbandingan. Oleh karena itu, dilihat variabel lainnya yang signifikan pada $\alpha=10 \%$ yaitu ARIMAX $(0,1,0)$ dengan covariate google trends kata kunci loker, $\mathrm{d}($ loker $)$, bisnis, $\mathrm{d}(\mathrm{job})$ dan d(bursa kerja). Skenario 2 tidak terdapat satupun model ARIMAX yang memiliki koefisien signifikan pada taraf signifikansi $\alpha=5 \%$. Namun, karena variabel ekonomi digunakan sebagai variabel kontrol maka akan tetap digunakan. Untuk Skenario 3, model yang dipilih adalah model yang memuat seluruh kombinasi variabel ekonomi makro dan indeks Google Trends yang disebutkan sebelumnya.Tahapan selanjutnya adalah evaluasi pada model yang dipilih. Berikut hasil ringkasan pemilihan model terbaik TPT Indonesia dan Jawa Barat.

Tabel 7. Ringkasan Hasil Pemilihan Model Terbaik TPT Indonesia dan Jawa Barat.

\begin{tabular}{|c|c|c|c|c|c|c|c|c|c|}
\hline \multirow[b]{2}{*}{ Model } & \multirow[b]{2}{*}{$\mathrm{X}_{1}$} & \multirow[b]{2}{*}{$\mathrm{X}_{2}$} & \multicolumn{3}{|c|}{ Uji Diagnostik } & \multicolumn{4}{|c|}{ Kriteria Pemilihan } \\
\hline & & & $\begin{array}{l}\text { Uji } \\
\text { LB }\end{array}$ & $\begin{array}{l}\text { Uji } \\
\text { JB }\end{array}$ & $\begin{array}{c}\text { Non } \\
\text { multiko- } \\
\text { linieritas }\end{array}$ & $\begin{array}{c}\text { Adjusted } \\
R^{2}\end{array}$ & AIC & $\mathrm{SC}$ & HQ \\
\hline \multicolumn{10}{|c|}{ Indonesia } \\
\hline \multirow{3}{*}{$\begin{array}{c}\text { ARIMAX } \\
(1,1,0) \\
\text { skenario } 1\end{array}$} & $\begin{array}{c}\text { Lowongan } \\
\text { _kerja }\end{array}$ & & V & & & 0,25638 & 100,371 & 119,054 & 106,348 \\
\hline & Bisnis & & V & V & & 0,25474 & 100,584 & 119,267 & 106,561 \\
\hline & $\begin{array}{c}\begin{array}{c}\text { Peluang } \\
\text { usaha }\end{array} \\
\end{array}$ & & $\mathrm{X}$ & $\mathrm{V}$ & & 0,37018 & 0,84044 & 102,727 & 0,90021 \\
\hline \multirow{4}{*}{$\begin{array}{c}\text { ARIMAX } \\
(1,1,0) \\
\text { skenario } 2 \\
\end{array}$} & & & $\mathrm{~V}$ & $\mathrm{~V}$ & & 0,20673 & 106,665 & 125,348 & 112,642 \\
\hline & Inf_mom & & $\mathrm{V}$ & $\mathrm{V}$ & & 0,14569 & 113,988 & 132,670 & 119,964 \\
\hline & $\mathrm{D}(\mathrm{Pe})$ & & $\mathrm{V}$ & $\mathrm{V}$ & & 0,14793 & 113,325 & 132,008 & 119,302 \\
\hline & D(Inf_mom) & & $\mathrm{V}$ & $\mathrm{V}$ & & 0,18746 & 107,596 & 126,278 & 113,572 \\
\hline \multirow{6}{*}{$\begin{array}{c}\text { ARIMAX } \\
(1,1,0) \\
\text { skenario } 3\end{array}$} & \multirow{3}{*}{$\mathrm{Pe}$} & $\begin{array}{c}\mathrm{D} \text { (Lowongan } \\
\text { _kerja) }\end{array}$ & $\mathrm{V}$ & $\mathrm{V}$ & $\mathrm{V}$ & 0,22342 & 107,318 & 130,671 & 114,789 \\
\hline & & $\mathrm{D}$ (Bisnis) & V & V & V & 0,25756 & 102,428 & 125,781 & 109,899 \\
\hline & & D(Peluang_usaha) & $\mathrm{V}$ & $\mathrm{V}$ & V & 0,17524 & 113,320 & 136,672 & 120,790 \\
\hline & \multirow{3}{*}{ Inf_mom } & $\begin{array}{l}\text { D(Lowongan } \\
\text { _kerja) }\end{array}$ & V & V & V & 0,16690 & 114,223 & 137,576 & 121,694 \\
\hline & & D(Bisnis) & $\mathrm{V}$ & $\mathrm{V}$ & $\mathrm{V}$ & 0,20223 & 109,585 & 132,939 & 117,056 \\
\hline & & D(Peluang_usaha) & $\mathrm{V}$ & $\mathrm{V}$ & $\mathrm{V}$ & 0,11272 & 120,486 & 143,839 & 127,957 \\
\hline
\end{tabular}


Tabel 7. Ringkasan Hasil Pemilihan Model Terbaik TPT Indonesia dan Jawa Barat (lanjutan).

\begin{tabular}{|c|c|c|c|c|c|c|c|c|c|}
\hline \multirow[b]{2}{*}{ Model } & \multirow[b]{2}{*}{$\mathrm{X}_{1}$} & \multirow[b]{2}{*}{$\mathrm{X}_{2}$} & \multicolumn{3}{|c|}{ Uji Diagnostik } & \multicolumn{4}{|c|}{ Kriteria Pemilihan } \\
\hline & & & $\begin{array}{l}\text { Uji } \\
\text { LB }\end{array}$ & $\begin{array}{l}\text { Uji } \\
\text { JB }\end{array}$ & $\begin{array}{l}\text { Non } \\
\text { multiko- } \\
\text { linieritas }\end{array}$ & Adjusted $R^{2}$ & AIC & $\mathrm{SC}$ & HQ \\
\hline & & $\begin{array}{c}\text { Lowongan } \\
\text { _kerja }\end{array}$ & $\mathrm{V}$ & V & V & 0,30391 & 0,97076 & 120,430 & 104,547 \\
\hline & $\mathrm{D}(\mathrm{Pe})$ & Bisnis & V & V & V & 0,30299 & 0,97178 & 105,313 & 104,649 \\
\hline & & $\begin{array}{c}\text { D(Peluang } \\
\text { _usaha) }\end{array}$ & $\mathrm{V}$ & V & V & 0,11384 & 119,990 & 143,344 & 127,461 \\
\hline & & $\begin{array}{c}\text { Lowongan } \\
\text { _kerja }\end{array}$ & V & V & V & 0,26363 & 100,982 & 124,335 & 108,453 \\
\hline & D(inf_mom) & Bisnis & V & V & $\mathrm{V}$ & 0,28023 & 0,98693 & 122,047 & 106,164 \\
\hline & & $\begin{array}{c}\text { Peluang } \\
\text { _usaha }\end{array}$ & $\mathrm{V}$ & V & V & 0,38454 & 0,83310 & 106,664 & 0,90781 \\
\hline & & & & wa B & & & & & \\
\hline & Loker & & $\mathrm{V}$ & $\mathrm{V}$ & & 0,07907 & 121,102 & 130,443 & 124,090 \\
\hline ARIMAX & d(loker) & & $\mathrm{V}$ & V & & 0,07882 & 121,129 & 130,470 & 124,117 \\
\hline$(0,1,0)$ & Bisnis & & $\mathrm{V}$ & V & & 0,09472 & 119,388 & 128,729 & 122,377 \\
\hline skenario & d(bisnis) & & $\mathrm{V}$ & V & & 0,21175 & 105,545 & 114,886 & 108,533 \\
\hline 1 & $\mathrm{D}(\mathrm{job})$ & & $\mathrm{V}$ & V & & 0,06151 & 122,990 & 132,332 & 125,979 \\
\hline & d(bursa_kerja) & & $\mathrm{X}$ & $\mathrm{V}$ & & 0,08817 & 120,109 & 129,450 & 123,097 \\
\hline ARIMAX & $\mathrm{Pe}$ & & $\mathrm{V}$ & $\mathrm{V}$ & & $-0,03095$ & 132,386 & 141,728 & 135,375 \\
\hline$(0,1,0)$ & Inf_mom & & $\mathrm{V}$ & V & & 0,01277 & 128,053 & 137,395 & 131,042 \\
\hline skenario & $\mathrm{D}(\mathrm{Pe})$ & & $\mathrm{V}$ & V & & $-0,03031$ & 132,325 & 141,666 & 135,313 \\
\hline 2 & D(Inf_mom) & & $\mathrm{V}$ & V & & $-0,03047$ & 132,340 & 141,681 & 135,328 \\
\hline \multirow{24}{*}{$\begin{array}{c}\text { ARIMAX } \\
(0,1,0) \\
\text { skenario } \\
3\end{array}$} & \multirow{6}{*}{$\mathrm{Pe}$} & loker & $\mathrm{V}$ & V & V & 0,04846 & 127,401 & 141,413 & 131,883 \\
\hline & & d(loker) & $\mathrm{V}$ & V & V & 0,05291 & 126,932 & 140,944 & 131,415 \\
\hline & & Bisnis & $\mathrm{V}$ & V & V & 0,06947 & 125,168 & 139,180 & 129,651 \\
\hline & & D(Bisnis) & $\mathrm{V}$ & V & V & 0,21136 & 108,624 & 122,636 & 113,106 \\
\hline & & $\mathrm{D}(\mathrm{Job})$ & $\mathrm{V}$ & V & V & 0,02763 & 129,566 & 143,578 & 134,049 \\
\hline & & $\begin{array}{c}\text { D(Bursa } \\
\text { kerja) }\end{array}$ & $\mathrm{X}$ & V & V & 0,05455 & 126,760 & 140,771 & 131,242 \\
\hline & \multirow{6}{*}{ Inf_mom } & $\mathrm{D}$ (Loker) & $\mathrm{X}$ & $\mathrm{V}$ & $\mathrm{V}$ & 0,11106 & 120,596 & 134,608 & 125,079 \\
\hline & & loker & $\mathrm{V}$ & V & V & 0,04986 & 127,254 & 141,266 & 131,736 \\
\hline & & Bisnis & $\mathrm{V}$ & V & V & 0,07386 & 124,696 & 138,708 & 129,179 \\
\hline & & D(Bisnis) & V & V & V & 0,24060 & 104,846 & 118,858 & 109,329 \\
\hline & & $\mathrm{D}(\mathrm{Job})$ & $\mathrm{V}$ & V & V & 0,06261 & 125,903 & 139,915 & 130,385 \\
\hline & & $\begin{array}{c}\text { D(Bursa } \\
\text { kerja) }\end{array}$ & $\mathrm{X}$ & V & V & 0,08028 & 124,000 & 138,012 & 128,482 \\
\hline & \multirow{6}{*}{$\mathrm{D}(\mathrm{Pe})$} & Loker & $\mathrm{V}$ & $\mathrm{V}$ & $\mathrm{V}$ & 0,05651 & 126,552 & 140,564 & 131,034 \\
\hline & & d(loker) & $\mathrm{V}$ & V & V & 0,05016 & 127,223 & 141,235 & 131,706 \\
\hline & & Bisnis & $\mathrm{V}$ & V & V & 0,06603 & 125,537 & 139,549 & 130,020 \\
\hline & & D(Bisnis) & $\mathrm{V}$ & V & V & 0,18633 & 111,749 & 125,761 & 116,231 \\
\hline & & $\mathrm{d}(\mathrm{Job})$ & $\mathrm{V}$ & V & V & 0,02764 & 129,565 & 143,577 & 134,048 \\
\hline & & $\begin{array}{c}\text { d(Bursa } \\
\text { kerja) }\end{array}$ & $\mathrm{V}$ & V & V & 0,07146 & 124,954 & 138,966 & 129,437 \\
\hline & \multirow{6}{*}{ D(Inf_mom) } & Loker & $\mathrm{V}$ & $\mathrm{v}$ & $\mathrm{v}$ & 0,04998 & 127,242 & 141,254 & 131,724 \\
\hline & & d(loker) & $\mathrm{v}$ & $\mathrm{v}$ & $\mathrm{v}$ & 0,04492 & 127,772 & 141,784 & 132,255 \\
\hline & & Bisnis & $\mathrm{v}$ & $\mathrm{v}$ & $\mathrm{v}$ & 0,06806 & 125,320 & 139,332 & 129,803 \\
\hline & & D(Bisnis) & $\mathrm{v}$ & $\mathrm{v}$ & $\mathrm{v}$ & 0,18304 & 112,152 & 126,164 & 116,635 \\
\hline & & $\mathrm{d}(\mathrm{Job})$ & $\mathrm{v}$ & $\mathrm{v}$ & $\mathrm{v}$ & 0,06024 & 126,156 & 140,168 & 130,638 \\
\hline & & d(Bursa_kerja) & $\mathrm{v}$ & $\mathrm{v}$ & $\mathrm{v}$ & 0,06278 & 125,885 & 139,897 & 130,368 \\
\hline
\end{tabular}

Berdasarkan Tabel 7 dapat diketahui bahwa untuk TPT Indonesia model ARIMAX $(1,1,0)$ terbaik, yang mana memenuhi asumsi white noise, error berdistribusi normal adalah skenario 1 dengan covariate "lowongan kerja", skenario 2 dengan covariatee pertumbuhan ekonomi dan skenario 3 yang memenuhi asumsi non multikolinieritas dengan covariate perubahan pertumbuhan ekonomi dan "lowongan kerja" serta model ARIMAX $(1,1,0)$ dengan covariate perubahan inflasi bulanan dan "peluang usaha". Sementara itu, untuk TPT Jawa Barat model ARIMAX $(0,1,0)$ terbaik adalah skenario 1 dengan covariate perubahan "bisnis", skenario 2 dengan covariate inflasi bulanan dan skenario 3 dengan covariate inflasi bulanan dan d(bisnis). 
Selanjutnya dilakukan peramalan pada model terbaik masing-masing skenario. Kemudian dibandingkan tingkat akurasinya antar model untuk mengetahui model mana yang memberikan hasil terbaik.

Tabel 8. Perbandingan model ARIMAX untuk TPT Jawa Barat.

\begin{tabular}{|c|c|c|c|}
\hline Model & RMSE & MAE & MAPE \\
\hline \multicolumn{4}{|l|}{ Indonesia } \\
\hline ARIMAX $(1,1,0)+$ GT lowongan kerja & 0,301523 & 0,239867 & 3,542073 \\
\hline ARIMAX $(1,1,0)+$ Pertumbuhan Ekonomi & 0,320182 & 0,246384 & 3,643383 \\
\hline ARIMAX $(1,1,0)+D$ (pertumbuhan ekonomi $)+$ GT lowongan kerja & 0,294919 & 0,219644 & 3,328732 \\
\hline ARIMAX $(1,1,0)+$ D(inflasi bulanan) + GT peluang usaha & 0,278942 & 0,229253 & 3,612752 \\
\hline \multicolumn{4}{|l|}{ Jawa Barat } \\
\hline ARIMAX $(1,1,0)+\mathrm{D}(\mathrm{GT}$ Bisnis $)$ & 0,383705 & 0,308274 & 2,964217 \\
\hline ARIMAX $(1,1,0)+$ inflasi bulanan & 0,429412 & 0,319887 & 3,026694 \\
\hline ARIMAX $(1,1,0)+$ inflasi bulanan + D(GT Bisnis $)$ & 0,369832 & 0,300259 & 2,905997 \\
\hline
\end{tabular}

Model yang memberikan nilai RMSE, MAE, MAPE terkecil adalah mdel yang terbaik untuk peramalan. Berdasakan Tabel 8 dapat dilihat Model $\operatorname{ARIMAX}(1,1,0)$ skenario 3 dengan covariate perubahan pertumbuhan ekonomi dan indeks google trends kata kunci "lowongan kerja" lebih baik dibandingkan model lainnya untuk meramal TPT di Indonesia secara umum. Berikut ini persamaan yang terbentuk.

$$
\begin{gathered}
T P T_{t}=-0.0118+0.2920 T P T_{t-1}+0.7080 T P T_{t-2}-0.1464 D(P E)_{t} \\
-0.0043 \text { Lowong_kerja }_{t}
\end{gathered}
$$

Model ARIMAX $(0,1,0)$ skenario 3 dengan covariate inflasi bulanan dan perubahan indeks google trends kata kunci "bisnis" lebih baik dibandingkan model lainnya dalam meramal TPT Jawa Barat.

$$
T P T_{t}=-0.1610+T P T_{t-1}-0.2566 \text { inf__mom }{ }_{t}-0.0139{\text { (bisnis })_{t}}
$$

Selanjutnya, dilakukan peramalan untuk beberapa periode ke depan berdasarkan persamaan di atas. Sehingga didapatkan hasil sebagai berikut.

Tabel 9. Hasil peramalan dan Data Aktual TPT Indonesia dan Jawa Barat

\begin{tabular}{ccccc}
\hline \multirow{2}{*}{ Periode } & \multicolumn{2}{c}{ TPT Indonesia } & \multicolumn{2}{c}{ TPT Jawa Barat } \\
\cline { 2 - 5 } & Hasil Peramalan & Data Aktual (BPS) & Hasil Peramalan & Data Aktual (BPS) \\
\hline$(1)$ & $(2)$ & $(3)$ & $(4)$ & $(5)$ \\
2019 S1 & 5,029729 & 4,98 & 8.053950 & 7,78 \\
2019 S2 & 5,093950 & 5,23 & 7.532823 & 8,04 \\
2020 S1 & 5,234100 & 4,94 & 7,785507 & 7,71 \\
2020 S2 & 5,819776 & 7,07 & 7,597328 & 10,46 \\
2021 S 1 & 5,922844 & 6,26 & 10,236346 & 8,92 \\
\hline
\end{tabular}

Berdasarkan Tabel 9 dapat dilihat bahwa hasil peramalan untuk periode Agustus 2020 dan Februari 2021 cukup berbeda dengan data tingkat pengangguran terbuka yang dipublikasikan oleh BPS. Hal ini disebabkan karena adanya perubahan ekstrim akibat pengaruh pandemi COVID-19 yang menyebabkan tingkat pengangguran meningkat (CNN Indonesia, 2020). Model ARIMAX yang merupakan model peramalan berdasarkan data historis yang sebelumnya tergolong rendah, tidak mampu mendeteksi hal tersebut karena periode penelitian tidak mencakup masa pandemi. Namun, walaupun hasil peramalan cukup berbeda, pergerakan indeks Google Trends dengan kata kunci "lowongan kerja" memiliki pergerakan yang beriringan dengan TPT Indonesia seperti pada Gambar 3 dan begitu pula untuk kondisi di Jawa Barat, pergerakan indeks Google Trends dengan kata kunci "bisnis" memiliki pergerakan yang beriringan dengan TPT Jawa Barat.

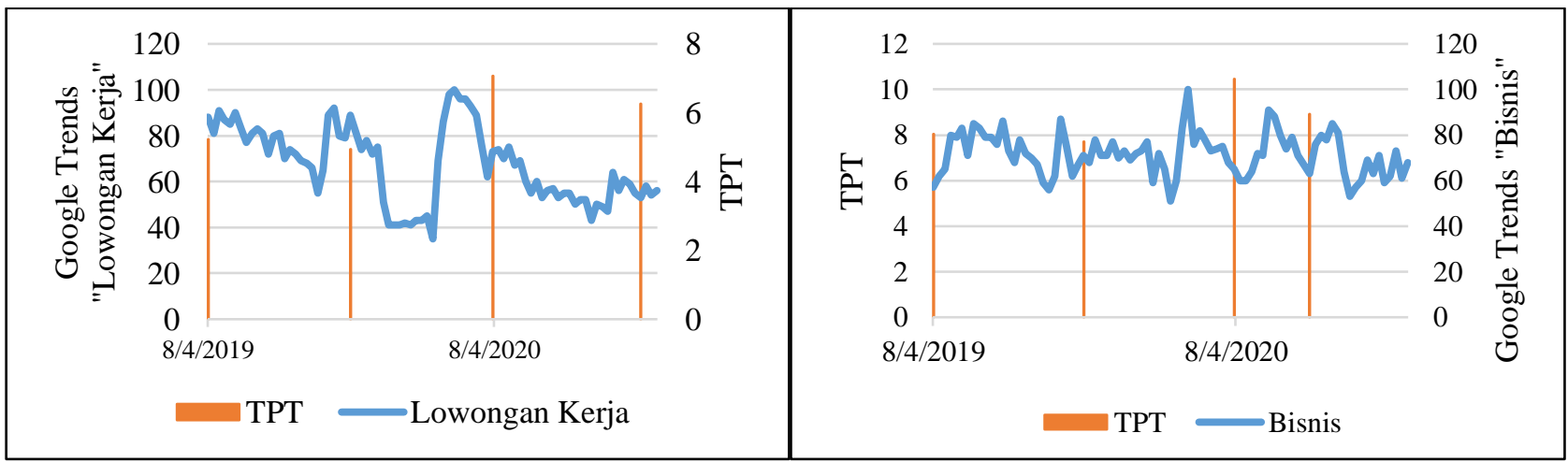

Gambar 3. Google trends dan TPT Indonesia (kiri)/TPT Jawa Barat (kanan) Agustus 2019-Februari 2021 


\section{KESIMPULAN}

Data dari Google Trends dapat digunakan untuk meramalkan tingkat pengangguran terbuka (TPT) baik pada tingkat nasional maupun pada tingkat regional di Provinsi Jawa Barat dengan tingkat akurasi peramalan yang cukup baik. Namun, perlu kehati-hatian menggunakan data historis untuk peramalan jika terjadi kondisi ekstrim seperti COVID-19. Peramalan TPT baik pada tingkat nasional maupun pada tingkat regional di Provinsi Jawa barat dengan menambahkan data Google Trends ke dalam model bersamaan variabel ekonomi makro mampu memberikan akurasi yang lebih baik daripada model yang hanya menggunakan variabel ekonomi makro saja sebagai prediktor. Penggunaan data penunjang Google Trends dalam peramalan TPT pada tingkat nasional memberikan akurasi yang lebih baik daripada tingkat regional di Provinsi Jawa Barat.

\section{DAFTAR PUSTAKA}

Badan Pusat Statistik. (2020). Keadaan Angkatan Kerja di Indonesia Agustus 2020. Jakarta: BPS

Baltagi, B. H. (2008). Econometrics (4th ed). New York: Springer Verlag Berlin Heidelberg.

CNN Indonesia. (5 November 2020). Pengangguran RI Melonjak Jadi 9,77 Juta per Agustus 2020. CNN Indonesia. Diakses Pada 9 Juli 2021 https://www.cnnindonesia.com/ekonomi/20201105124256-532566255/pengangguran-ri-melonjak-jadi-977-juta-per-agustus-2020.

Gujarati, D.N. (2004). Basic Econometrics (4th ed). New York: McGraw-Hill.

Kementerian Kominfo. "Masuki Era Revolusi Industri 4.0, Indonesia Perlu Manfaatkan Teknologi Digital". Berita Kominfo 4 Oktober 2020. 6 Juni 2021. https://www.kominfo.go.id/content/detail/29885/masukiera-revolusi-industri-40-indonesia-perlu-manfaatkan-teknologi-digital/0/berita_satker.

Makridakis, S. G., Wheelwright, S. C., \& Hyndman, R. J. Forecasting: Methods and Application (2nd ed). New York: Wiley.

Mankiw, N. G. (2003). Macroeconomics (5th ed). New York: Worth Publisher.

Mihaela, S. (2020). Improving unemployment rate forecasts at regional level in Romania using Google Trends. $\begin{array}{lllllll}\text { Technological Forecasting \& } & 155 & \text { (2020), } & 120026 .\end{array}$ https://doi.org/10.1016/j.techfore.2020.120026.

Neter, J., Wasserman, W., \& Kutner, M. H. (1989). Applied linear regression models. Boston: IRWIN

Nooraeni, R., Purba, N. S., \& Yudho, N. P. (2020). Using Google Trend Data as an Initial Signal Indonesia Unemployment Rate. Proceedings of $62^{\text {th }}$ ISI World Statistics Congress 2019, Kuala Lumpur: 18-23 Agustus 2019, 266-274.

Önder, I., \& Gunter, U. (2016). Forecasting tourism demand with Google Trends: the case of Vienna. Tourism Analysis, 21(2), 203-220. https://doi.org/10.3727/108354216X14559233984773.

Smith, E., \& White, S. (2011). What Insights Can Google Trends Provide About Tourism in Specific Destinations. the $2^{\text {nd }}$ International Conference on the Measurement and Economic Analysis of Regional Tourism, Bilbao: 27-29 Oktober 2011.

Utomo, A. S. (2020). Pemanfaatan Data Situs Lowongan Kerja dan Google Trends untuk Statistik Ketenagakerjaan [Skripsi]. Jakarta: Politeknik Statistika STIS.

We Are Social \& Hootsuite. (2019). Indonesian Digital Report 2019. We Are Social \& Hootsuite. 20 November 2020. https://datareportal.com/reports/digital-2019-indonesia. 